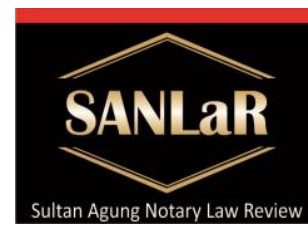

\title{
Juridical Review of Name Loan Agreements in Controlling Property Rights to Land in Indonesia
}

\author{
Afriyati Wahyningrum* ${ }^{*}$
}

*) Students of Master of Notary Law, Faculty of Law, Universitas Islam Sultan Agung (UNISSULA) Semarang, E-mail: afdandiputraputri@gmail.com

\begin{abstract}
This research is entitled Juridical Review of Name Loan Agreement (Nominee) in Ownership of Land in Indonesia. This research aims to find out (1) a juridical review of ownership rights over land of foreign citizens in investment activities in Indonesia and (2) the legal status or consequences of foreign citizens in investing in Indonesia. The problem in this research is the inequality between ideality and reality. There are still many practices of controlling ownership of land by foreign citizens through Nominee Agreements using the guise of Indonesian citizens so that it seems as if they do not violate the law. Even this action was legalized by the Notary/PPAT who in fact clearly understood the applicable law. This study uses a normative juridical approach. The method used in data processing and data analysis used in this study is a qualitative method, which is a descriptive analytical data analysis method that refers to a particular problem or is based on applicable laws and regulations. The results of this study indicate that the making of deeds made by notaries regarding land sale and purchase by borrowing name or nominee agrement is null and void for the sake of law this violates the Civil Code articles 1335 and 1337 of the Civil Code and article 33 paragraph (3) of the 1945 Constitution and Article 21 paragraph (1) and 26 paragraphs (20 UUPA, also violate the rights of the Indonesian people over Indonesian territory. that is, a descriptive analytical data analysis method that refers to a particular problem or is based on the prevailing laws and regulations. The results of this study indicate that the making of deeds made by notaries regarding land sale and purchase by borrowing name or nominee agrement is null and void for the sake of law this violates the Civil Code articles 1335 and 1337 of the Civil Code and article 33 paragraph (3) of the 1945 Constitution and Article 21 paragraph (1) and 26 paragraphs (20 UUPA, also violate the rights of the Indonesian people over Indonesian territory. that is, a descriptive analytical data analysis method that refers to a particular problem or is based on the prevailing laws and regulations. The results of this study indicate that the making of deeds made by notaries regarding land sale and purchase by borrowing name or nominee agrement is null and void for the sake of law this violates the Civil Code articles 1335 and 1337 of the Civil Code and article 33 paragraph (3) of the 1945 Constitution and Article 21 paragraph (1) and 26 paragraphs (20 UUPA, also violate the rights of the Indonesian people over Indonesian territory.
\end{abstract}

Keywords : Notary; Nominee Agreement; Tenure of Land Rights. 


\section{Introduction}

Land is an important part of life whose existence must be utilized maximally for the benefit of the people. As the relationship between humans and land was put forward by Gouw Giok Siong ${ }^{1}$ who says that: "The land is very closely related to human life. Everyone certainly needs land, not even just in his life. To die, humans still need a piece of land. "

Reflection on land has a very strategic meaning, because it contains not only physical aspects but also social, economic, cultural, even political aspects, as well as defense, security and law. ${ }^{2}$ The strong relationship between humans and land demands legal protection so that humans can exercise their rights safely. Legal protection and reference for land policies in Indonesia as contained in Article 33 paragraph (3) of the 1945 Constitution of the Republic of Indonesia states:

"Earth and water and the natural resources contained therein shall be controlled by the state and used for the greatest prosperity of the people".

Furthermore, the realization of the legal relationship between humans and land is regulated in Act No. 5 of 1960 concerning Basic Agrarian Principles, or what is known as the Basic Agrarian Law (hereinafter referred to as UUPA). This new Agrarian Law is based on the provisions of Customary Law, because Customary Law is the original Indonesian People's Law. ${ }^{3}$

Regarding the subject who can be granted and have land rights, according to the Nationality Principle stated in the UUPA, it is stipulated in Article 9 paragraph (1) which states that only Indonesian citizens (hereinafter referred to as Indonesian citizen) can have a full relationship with the earth, water, and space. In the explanation of the article, only Indonesian citizens can become the subject of property rights, not foreign citizens (hereinafter referred to as foreigners). In addition, the UUPA also regulates the forms of land tenure by foreigners in the form of Use Rights and Lease Rights as regulated in Article 42 sub b and Article 45 sub b. However, foreign ownership of land is clearly prohibited by the state.

As for Islam, it does not clearly regulate the prohibition of land ownership by foreigners, but land ownership is explained in the legal object of muamalat which concerns civil matters in material relations. Ownership is a relationship between a person and the assets he owns, so that the owner has special authority over his property to carry out transactions provided that the way of ownership of his property is justified by syara '. In accordance with the arguments of the Al-Qur'an

\footnotetext{
${ }^{1}$ Gow Giok Siong. (2000). Interpretation of the Basic Agrarian Law. Jakarta: Keng Po. p. 46.

${ }^{2}$ FXSumarja. (2012). The Problems of Land Ownership for Foreigners-A Philosophical Juridical Review. Bandar Lampung: Independent Publishing, p.V.

${ }^{3}$ Boedi Harsono. (2008). Indonesian Agrarian Law: History of the Formation of Basic Agrarian Laws, Content and Implementation. Jakarta: Djambat. p. 139
} 
Surah Al-Baqarah verse 188:

$$
\text { ولا تأكلوا أمولكم بينكم بآلبطل وتدلوا بها إلى آلحكام لتأكلوا فريقا من أمول آلناس بآلإثم وأنتم تعلمون }
$$

Meaning:"And do not eat part of the wealth among you in an immoral way and (do not) bring (the affairs) of that property to the judge, so that you can eat a portion of the other person's property by (sinning), even though you are knowing."

Ownership can be prohibited if it causes trouble for others and violates the law. Sharia gives full power to the state to punish activities that are not in accordance with the regulations in force in that country. ${ }^{4}$

The extent of authority contained in Freehold Rights over Land, while foreigners are not allowed to own it, there are many ways that foreigners can take over land with Freehold Rights in Indonesia. Currently, there are many forms of political expansion for foreigners in terms of investment in Indonesia. By establishing a high-profile company then owning several assets, including the land which is authorized by a Nominee Agreement. Regarding this, it is clear that it has been regulated in Article 33 paragraph (1) and (2) of Act No. 25 of 2007 concerning Investment (hereinafter referred to as UUPM) as follows:

1. Domestic investors and foreign investors who invest in the form of a limited liability company are prohibited from entering into agreements and/or statements confirming that share ownership in a limited liability company is for and on behalf of other people; and

2. In the event that a domestic investor and a foreign investor make an agreement and/or statement as referred to in paragraph (1), the agreement and/or statement shall be declared null and void by law.

Especially with the political changes in the New Order, a lot of land was actually controlled by a group of foreign investors. ${ }^{5}$ This condition is evident from various regulations issued by the government, such as the October 1993 deregulation policy which simplified the process of granting Business Use Rights (HGU) and Building Use Rights (HGB). ${ }^{6}$

Even since 1953, according to S. Poerwopranoto's opinion, as long as the prohibition on selling land to foreigners still exists, of course foreigners will try to

\footnotetext{
${ }^{4}$ Muhammad Abdul Manan. (1995). Theory and Practice of Islamic Economics. Yogyakarta: Bhakti Waqf Fund. p. 70.

${ }^{5}$ Gunawan Wiradi. (2001). Principles of Agrarian Reform for the Way of People's Livelihoods and Prosperity. Yogyakarta: Lapera Pustaka Utama. p. 163.

${ }^{6}$ Maria SW Sumardjono. (2009). Land in the Perspective of Economic, Social and Cultural Rights. Jakarta: Kompas. p. 23.
} 
violate it, for example by using Indonesian citizens as intermediary. ${ }^{7}$ Through a Nominee Agreement, it is as if a foreigner can own land with Freehold Rights in Indonesia by registering the land in the name of the Indonesian Citizen whom he appoints as a Nominee.

Nominee agreements are completely unknown in the Indonesian Legal System, especially in the Indonesian Agreement Law, and there is no specific and firm regulation, so that it can be said to contain an empty meaning or empty norm. The emergence of the Nominee Agreement is a form of legal imperfection in Indonesia which is then used by foreigners for their own interests. From some of these descriptions, the authors are interested in conducting research with the title "Judicial Review of Nominee Agreements in Mastery of Land Ownership in Indonesia".

\section{Research Methods}

According to F. Sugeng Istanto, research is a series of activities that lead to a result, namely the disclosure of the truth. ${ }^{8}$ Specifically, F. Sugeng Istanto defines legal research as research that helps the development of legal science in revealing legal truth. Law science in question is the science that studies Positive Law. $^{9}$

\subsection{Approach Method}

Research on "Judicial Review of Nominee Agreements in Control of Land Ownership in Indonesia" is a study that uses a normative juridical approach. The method used in data processing and data analysis used in this study is a qualitative method, which is a descriptive analytical data analysis method that refers to a particular problem or is based on applicable laws and regulations.

\subsection{Specification Research and Discussion}

The results of this research are set forth in the form of a prescriptive report, namely studying the objectives of the law, the values of justice, the validity of the rule of law, legal concepts, and legal norms. ${ }^{10}$ Prescriptive type of research is research aimed at getting suggestions about what to do to solve certain problems. ${ }^{11}$

The type of prescriptive research here is adapted to the prescriptive nature of legal science, where the discussion is usually ended by providing certain

\footnotetext{
7 https://kependempatpemdadiy.files.wordpress.com/2010/09/l Report-triwulan-iii-datapopulation-year-2012-province-diy-accent.pdf. accessed on 29 April 2018.

${ }^{8}$ Sugeng Istanto. (2007). Legal Research. Yogyakarta: CV Ganda. p. 2.

${ }^{9}$ Ibid, p. 30.

${ }^{10}$ Peter Mahmud Marzuki. (2010). Legal Research. Jakarta: Kencana, p. 22.

${ }^{11}$ Soerjono Soekanto. (2010). Introduction to Legal Research. UI Press. Jakarta. p. 10.
} 
formulas. ${ }^{12}$ The usefulness of prescriptive research in this research is to formulate or create mandatory and policy guidelines for mitigating the impacts resulting from the birth of the Nominee Agreement.

In this study, after obtaining a clear picture of the problems in the Nominee Agreement in terms of ownership of Land Rights, suggestions for the problem will be given so that they can be used as guidelines for problems related to the research topic, namely the Nominee Agreement. Types of Sources and Data

Sources of data in this study consisted of:

\section{a. Data Primary}

In writing this is the practice of Nominee Agreement in Indonesia. Data collection is one of the stages in the research process which is absolutely necessary because data is the source to be studied. Data collection is focused on the main problems that exist, so that in the study there is no deviation and confusion in the discussion.

\section{b. Data Secondary}

Secondary data in this study using library research. Library research data collection tool, namely the document study carried out by collecting, studying, and analyzing library materials related to the object of this research. Legal materials used in legal research consist of primary legal materials, secondary legal materials, and tertiary legal materials with the following explanation:

- Primary legal materials are binding legal materials, consisting of :

1) The 1945 Constitution of the Republic of Indonesia;

2) Code of Civil law;

3) Act No. 5 of 1960 concerning Basic Agrarian Regulations;

4) Act No. 25 of 2007 concerning Investment;

5) Government Regulation No. 40 of 1996 concerning Business Use Rights, Building Use Rights and Land Use Rights;

6) Government Regulation No. 41 of 1996 concerning Ownership of Residential or Residential Homes by Foreigners Domiciled in Indonesia; and

7) Regulation of the Minister of Agrarian Affairs/Head of BPN No. 8 of 1996 concerning Amendments to the Regulation of the Minister of Agrarian Affairs/Head of BPN No. 7 of 1996 concerning the Requirements for Foreigner Ownership of Residential or Occupancy Homes.

- Secondary legal materials are research materials that provide instructions and explanations for primary legal materials, which consist of

12 Peter Mahmud Marzuki, Op.Cit., p. 23. 
books, literature, papers, articles, internet data, research results and other scientific works related to this research.

- Tertiary legal materials are materials that provide guidance and explanation for primary and secondary legal materials such as general dictionaries, legal dictionaries, encyclopedias and so on. ${ }^{13}$

\section{Result and Discussion}

\subsection{Agreement in General}

\section{Definition of Agreement}

There are many definitions or meanings of agreement however, all of these definitions have elements in common. These definitions can be seen from various sources, such as laws and regulations, expert opinion and dictionaries, both Indonesian and other foreign languages. A legal expert, namely prof. Subekti argues that a covenant is an event where a person promises to another person or where the two people promise each other to do something. In addition, according to M. Yahya Harahap, "the meaning of an agreement or verbintenis is a legal relationship of property or property between two or more people which gives one party the power to gain achievements and the same time obliges the other party to fulfill the achievement.

A. Plito (quoted by R. Setiawan) using the term engagement for verbentenis argues: "An engagement is a legal relationship that is property between two or more people, on the basis of the name of the party with which one is entitled (creditor) and the other party is obliged ( debtor) for an achievement ". Furthermore, Subekti argued: "an engagement is a legal relationship (regarding property assets) between two people, which gives one the right to claim something from the other, while the other is obliged to fulfill the demands".

Sudikno Mertokusumo argued that the notion of an agreement itself is a legal relationship between two or more parties based on an agreement to have legal consequences. Meanwhile, Wirjono Prodjodikoro defines an agreement as a legal act regarding assets between two parties, in which one party promises or is deemed to promise to do something or not to do something, while the other party has the right to demand the implementation of that promise.

Based on some of the views of the scholars mentioned above, an agreement is an event arising from a relationship between two or more people who bind themselves to carry out something in the field of wealth.

\footnotetext{
13 Nomensen Sinamo. (2010). Legal Research Methods in Theory and Practice. Jakarta: Bumi Intitama Sejahtera. p. 16.
} 
Meanwhile, the meaning of the agreement itself, in book III (three) and Chapter II Article 1313 of the Civil Code which states: "an agreement (agreement) is an act whereby one or more people affirm themselves against one or more people".

An agreement is an event where a person promises to another person or where two or more people promise each other to do something.

An agreement is an act/legal action that causes, changes, removes rights or creates a legal relationship and in this way, the agreement creates legal consequences which are the objectives of the parties. If a legal act is an agreement, the people who take legal action are called parties.

The definition of the agreement, which is contained in Article 1313 of the Civil Code, is incomplete, and too broad. Incomplete, because what is formulated only concerns a one-sided agreement, while it is too broad, meaning that by using the word "act" it includes voluntary representation, and actions. against the law.

The definition of the agreement regulated in Article 1313 of the Civil Code, is actually inaccurate because there are several weaknesses, namely:

a. It only concerns one-sidedly.

It is known from the formulation of "one person" or more which binds itself to one or more other people. The word "to bind" is a verb whose nature only comes from one party only, not from both parties.

Meanwhile, the intent of the agreement is to bind the two parties, so that there appears to be a deficiency in which at least there is a need for a "mutually binding" formula. So it is clear that there is a consensus/agreement between the two parties making the agreement.

b. The word action includes no consensus/agreement.

In the sense of an act, it also includes taking care of the interests of others and acts against the law. Both of these are actions that do not contain consensus or without the will to cause legal consequences. Also the act itself has a very broad meaning, because in fact the intent of the action contained in the formula is a legal action, namely an act which gives rise to legal consequences.

From the above meanings of the agreement, the elements of the agreement can be drawn, namely:

a. There are parties of at least two people.

b. There is agreement.

c. There are goals to be achieved and there are achievements that are carried out. 
d. The existence of parties means the existence of the subject of the agreement which can be a person and/or legal entity, the subject must be capable of carrying out legal acts stipulated in the Law.

e. There is an agreement which means that what is offered by one party is accepted by the other party, while the goal to be achieved or what is meant is to meet the needs of the parties through agreements, laws, and morals. Then the performance that is carried out is an obligation that must be fulfilled by the parties in accordance with the conditions for the validity of the agreement.

\section{Principles of Covenant Law}

In the law of agreement, there are several principles, namely:

a. Principle of Consensualism

This principle means that an agreement is born from the second an agreement is reached between the two parties. The principle of consesualism can be concluded in Article 1320 paragraph (1) of the Civil Code, which states: "One of the conditions for the validity of the agreement is an agreement of both parties". This implies that the agreement is generally not held formally, but it is sufficient with the agreement of both parties.

\section{b. Binding Strength Principle (Pacta Sunt Servanda)}

The principle of Pacta Sunt Servanda deals with the consequences of the agreement. This can be concluded, in Article 1338 paragraph (1) of the Civil Code which states: "Agreements made legally, apply as law, for those who make them". This means that the parties must obey and carry out the obligations (achievements) in the agreement, as they are obeying the law.

\section{c. Principle of Freedom of Contract}

The principle of freedom of contract can be analyzed from the provisions of Article 1338 paragraph (1) of the Civil Code, which states: "All agreements that are legally made, apply as law for those who make them". The principle of freedom of contract is a principle that gives freedom to the parties to: ${ }^{14}$

1) Make or not make an agreement;

2) Enter into agreements with anyone;

3) Determine the contents of the agreement, its implementation and requirements;

4) Determine the form of the agreement, namely written or oral.

d. Principle of Trust

\footnotetext{
${ }^{14}$ Salim HS, Op.Cit, p. 158.
} 
This principle of trust implies that the parties who enter into an agreement must be able to foster trust between them. This means that one party believes that the other party will meet its achievements in the future, and vice versa. The agreement can be held well if the parties trust each other.

e. Principle of Legal Equations

The principle of legal equality is that the legal subject who enters into an agreement has the same position, rights and obligations in law, and is not differentiated from one another, even though the legal subject is of different skin color, religion and race.

\section{f. Principle of Balance}

The principle of balance is a principle that requires both parties to fulfill and carry out the agreement. The creditor has the power to demand achievement, and if necessary it can demand the repayment of the achievement through the debtor's wealth, but the debtor also bears the obligation, to carry out the agreement in good faith.

\section{g. The Principle of Legal Certainty}

The agreement as a legal figure must contain legal certainty. This certainty is revealed from the binding strength of the agreement, namely as a law for making it.

\section{h. Moral Principles}

This moral principle is bound in a fair engagement, where a voluntary act from a person cannot claim the right for him to sue the performance of the debtor. This can be seen in Zaakwarneming, where a person performs actions voluntarily (morally), the person concerned has a legal obligation to continue and complete his actions.

\section{i. Principle of Compliance}

This principle is stated in Article 1339 of the Civil Code, which relates to the provisions regarding the contents of the agreement. The agreement that is stated in the contents of the agreement according to the principle of propriety must give birth to a sense of justice both to the party who entered into the agreement as well as a sense of justice that exists in society.

\section{j. Customary Principles}

This principle is seen as part of the agreement. An agreement is not only binding, for what is expressly regulated, but also for things that are generally followed. Regulated in Article 1339 in conjunction with Article 1347 of the Civil Code. 
Article 1339 of the Civil Code, states:

An agreement is not only binding, for matters expressly stated in it, but also for everything which, according to the nature of the agreement, is required by propriety, custom or law.

Article 1347 of the Civil Code, states:

"Things according to custom are forever agreed upon, considered tacitly included in the agreement, although not expressly stated".

k. Principle of Protection

\section{Closing}

- Applicable legal provisions relating to the creation of a name loan deed (nominee arrangement). Basically, it is legally permitted by a notary publicly formally, but in the case of domestic land ownership, making a nominee arrangement by a notary is an act of smuggling in agrarian law and a nominee agreement in the case of land ownership is prohibited by law. Ownership of land for foreigners is prohibited and violations of this article are subject to legal sanctions, however, the law does not completely eliminate opportunities for foreign citizens and foreign legal entities to have rights over land, only in the form of building rights, rights to cultivate and lease rights. The nominee agreement made between foreign nationals and local residents is based on false causes, namely agreements made under the pretext of hiding causes that are not actually allowed,

- Legal consequences that arise in connection with making deeds nominee Agreement on ownership of land rights between local residents and foreign nationals, namely the nominee agreement is null and void, this is because the nominee agreement made by the notary is an act of legal smuggling which is contrary to the provisions of Article 9, Article 21 and Article 26 Paragraph (2) Act No. 5 of 1960 concerning Basic Agrarian Principles, which states that land ownership rights are fully attached to Indonesian citizens and only Indonesian citizens can have property rights, furthermore the nominee agreement is also made does not meet the objective requirements in the provisions of Article 1320 of the Civil Code, namely concerning lawful causes, which results in the nominee agreement being null and void by law.

\section{References}

Journal:

Sri Endah Wahyuningsih, Keterlibatan Pejabat Notaris Terhadap Perbuatan Melawan Hukum Dan Turut Serta Melakukan Tindak Kejahatan Dalam Pemalsuan Dokumen, Vol. 5 No 1 March 2018 
Books:

[1] Abdulkadir Muhamad. (2001). Etika Profesi Hukum. Bandung: Citra Aditya Bakti

[2] Bachtiar Mustafa. (1985). Hukum Agraria dan Perspektif. Bandung: Remaja Karya

[3] Lutfi Effendi. (2004). Pokok-Pokok Hukum Administrasi. Malang: Bayu Media Publishing

[4] Maria SW Sumarjono. (2006). Kebijakan Pertanahan Antara Regulasi dan Implementasi. Jakarta: Kompas

[5] Muchsin, Imam Koeswahyono and Soimin. (2010). Hukum Agraria Indonesia Dalam Perspektif Sejarah. Bandung: Refika Aditama

[6] Ngadino. (2019). Ketentuan Umum Tata Cara Pembuatan dan Pengisisan Akta. Semarang: UPT Penerbitan Universita PGRI Semarang Press

[7] Nomensen Sinamo. (2010). Metode Penelitian Hukum dalam Teori dan Praktek. Jakarta: Bumi Intitama Sejahtera

[8] R.Wiryono Prodjodikiro. (2010). Azas-Azas Hukum Pejanjian. Bandung: Mandar Maju

[9] Satjipto Rahardjo. (2000). Ilmu Hukum. Bandung: Citra Aditya Bakti

[10] Shidarta. (2006). Hukum Perlindungan Konsumen Indonesia, Edisi Revisi. Jakarta: Gramedia Widiasarana Indonesia

[11] Urip Santoso. (2010). Pendaftaran dan Peralihan Hak Atas Tanah. Jakarta: Kencana

Regulations:

[1] Constitution of the Republic of Indonesia of 1945

[2] Code of Civil law

[3] Act No. 5 of 1960 concerning Basic Agrarian Regulations

[4] Act No. 2 of 2014 concerning amendments to Act No. 30 of 2001 concerning the Position of Notary Public

[5] Government Regulation Number 24 of 1997 concerning Land Registration.

[6] Government Regulation Number 38 of 1963 concerning the Designation of Legal Entities that can have Ownership Rights to Land. 
[7] Government Regulation Number 24 of 1997 concerning Land Registration.

[8] Regulation of the Head of the Land Agency Number 1 of 2006 concerning Provisions for the Implementation of Government Regulation 37 of 1998 on the Position of Land Deed Making Officials.

Internet:

[1] https://kependempatpemdadiy.files.wordpress.com/2010/09/leporttriwulaiii-datakependempat-year-2012-provincial-diy-accent.pdf.

[2] https://triyani.wordpress.com/tag/nominee

[3] https // www.kompasiana.com/melianawaty/hak-hak/over-land 